\title{
MUCKRAKE AND MANCHU \\ The Image of China in the American Press, 1900-1912
}

\author{
BY JERRY ISRAEL \\ Assistant Professor of History, University of Pittsburgh
}

$\mathrm{I}$

$\mathrm{N}$ his lively account of modern American reform movements, Eric Goldman tells the story of the Alaskan miner who, upon having his progressive credentials challenged, responds, "Progressive! Progressive! I tell you I'm a full-fledged insurgent. Why man, I subscribe to thirteen magazines." While the story may be apocryphal, the reform "condition of excitement and irritation" existing in Theodore Roosevelt's America was surely encouraged and represented by the highly popular "expose" journalism of the day. ${ }^{1}$ From the coincidence of the joint reporting of political and business corruption by Lincoln Steffens, Ida Tarbell and Ray Stannard Baker in a January I903 McClure's, a decade of American history was written and read in new magazines such as Success, The American, and Everybody's and even in older but converted publications like Cosmopolitan, Munsey's and Collier's.

Defined critically by Theodore Roosevelt in 1906 as "muckraking," American magazines featured sensational stories and equally sensational circulations. Historians, however, have more or less neglected these magazines. After two scholarly studies in the I930's, "muckraking" passed from all but the briefest text-book attention. Only in this decade have historians begun again to examine the nature of muckraking, its ideology, personalities and dramatic decline and fall. ${ }^{2}$

\footnotetext{
${ }^{1}$ Eric Goldman, Rendezvous With Destiny (New York, 1953), p. I76.

${ }^{2}$ Compare two works of the 1930's, Cornelius Regier, The Era of the Muckrakers (Chapel Hill, 1932) and Louis Filler, Crusaders for American Liberalism (New York, 1939) with the more recent Arthur and Lila Weinberg, The Muckrakers (New York, 1961), Harvey Swados, Years of Conscience (Cleveland, 1962), David M. Chalmers, The Social and Political Ideas of the Muckrakers (New York, 1964), Peter Lyon, Success Story: The Life and Times of S.S. McClure (New York, 1963), and John Semonche, "The American Magazine of 1906-15, Principle vs. Profit," Journalism Quarterly, XL (Winter 1963), 36-44.
} 
One reason for the long-delayed and still sketchy study of the press of the period is that the historical handling of this era of American journalism is as difficult as it may be enjoyable. Libraries often have incomplete holdings and even when the magazines are available, they are always poorly indexed and often crumbling. More important, the sheer volume of these popular periodicals makes research necessarily selective.

To overcome these problems and misconceptions, the handiest tool is an avid reader's file of clippings. Short of the papers of Goldman's miner, no more valuable or interesting material can be found than that of William Elliot Griffis in the Special Collections of the Rutgers University Library. ${ }^{3}$ A Rutgers graduate, class of I 869, Griffis' own articles and books constitute some of the finest early-twentiethcentury studies of Japan, China and Korea. ${ }^{4}$ A perceptive reader of the magazines of his day, Griffis saved many articles which now can be found in his papers, especially in Boxes 26-28. This file reveals a general muckraking fascination with the Far East, especially concerning America's opportunity and responsibility to bring modern, "progressive" civilization to a mysterious and potentially magnificent "new China." Using Griffis' trained eye as a guide, students of twentieth century American domestic and foreign policy can explore a facet of muckraking previously unnoticed.

In the same year that Roosevelt accused the magazines of concentrating on society's dirt, he defined China as the real "storm center" of world interest. It was natural, therefore, that the Far East would become, to use a good muckraking word, a target for the magazines. Alongside such typically titled pieces as "The Reign of Boodle and the Rape of the Ballot in St. Louis," or the "ArmourRefrigerator Car Company Exposed," B.O. Flower's Arena for I 905 included an article on "Our Policy Toward China." The less

3 The Griffs Papers, in the Rutgers Library since 1928 , contain the private papers and extensive library of this world traveler. See Ardath W. Burks and Jerome Cooperman, "The William Elliot Griffis Collection," Journal of A sian Studies, XX (Nov. 1960), $6 \mathrm{I}-69$.

${ }^{4}$ Among his more important publications are America in the East (1899), China's Story in Myth, Legend and Annals ( I II I), Korea, the Hermit Nation (I882), and The Japanese Nation in Evolution (1 907). See Ardath W. Burks, "William Elliot Griffis, Class of 1869 ," Journal of the Rutgers University Library, XXIX (Sept. I 966), 9I-IOO. 
sensationalist Independent revealed the same interest in the Orient by leading off a I 9 I o issue with a double-barrelled attack on "What is the Matter With Milwaukee?" by socialist Victor L. Berger and "The Present Situation in China," as reported by a former American consul. ${ }^{5}$

The classic example of this "China muckraking" appeared in the widely-read Success for 1907 and I 908 . Following up his own work (as well as that of Samuel Hopkins Adams, Edward Bok and Upton Sinclair) into the evils of the domestic drug and meat-packing industries, Samuel Merwin traced a similar Chinese menace in "Drugging a Nation: The Story of China and the Opium Curse." To the muckraker, domestic evils and corruption prevented the distribution of much of America's wealth and blessings at home. Similarly in China, Merwin perceived, opium blocked the door to the successful spread of Western civilization. Clarifying this comparison, Merwin asked his reform-minded readers to "try and imagine a self-made politician outwitting and beating down the traditions of Tammany Hall in New York City." To understand why reforms lagged in China, he advised multiplying the troubles of the New Yorker by "a thousand or two."

The interest of the American press in Chinese affairs, as Griffis' files reveal, was more than just that of a successful muckraking variation, Oriental-style. It stressed and reinforced belief in America's commercial, financial and philanthropic future in China. That China should be saved mostly as an outlet for an American manufacturing surplus was set forth in numerous magazine pieces, but nowhere better than in the work of Albert Beveridge, Senator from Indiana. "What America is looking for is trade," Beveridge asserted. Commerce was a nation's food and when prosperous, a country's diet would be mostly exotic foreign food. "We cannot live upon ourselves," he warned. "We must dispose of our surplus abroad, and upon the sale of our surplus abroad depends the prosperous condition of all our commerce." Moving from introductory political economy to elementary political geography, Beveridge made his plan clear:

${ }^{5}$ The Arena, Vol. XXXIII (Jan.-June, I 905); The Independent, LXVIII (April 21 , 1910).

${ }^{6}$ Success, Vols. X-XI (Oct. I 907-April 1908). 
"the most populous portion of the surface of the earth does not control its own markets. This portion of the earth's surface is Asia, and especially the Empire of China with its 400,000,000 of consumers." ${ }^{\prime z}$

Commercially, at least in theory, China was the perfect example of Russell Conwell's fashionably popular concept of "acres of diamonds," as in fact one American journalist did describe it. America's geographical position, stable economy, farm and factory productivity, and abundant resources made failure remote. Equality of opportunity, meaning no territorial spheres of influence as developed by European powers in the I 890's, was all that was needed. The Nation defined the commercial as opposed to the territorial expansionism of the Open Door in the following way: "We do not need to seek an unfair advantage. An open door and no favor infallibly means for the United States . . . the greater share and gain in the commercial exploitation of China." ${ }^{8}$

A group of American railroaders and bankers did seek to extend United States interest beyond the bounds of commerce and to exploit the opportunity immediately. As engineer William Barclay Parsons proclaimed in McClure's in I900, "We of today are concerned not with what China will do eventually with progress but with what we ourselves can and should do with it now." The "we" in this case was the American China Development Company and out of this group came the plan to build a railroad from Hankow to Canton on a concession granted by China. Through the introduction of heavy capital industry in the power and transportation fields, there could be obtained what the magazines described as a "foothold in the east" and the "boundless riches of her [China's] mines and the hoarded wealth of centuries."

To swing open the door of China more freely to commerce and investment, the hinges were to be lubricated by American-inspired reform and progress. As The World's Work reviewed the situation,

${ }^{7}$ Albert Beveridge, "The White Invasion of China," Saturday Evening Post, CLXXIV (Nov. 16, I901), 3-4.

${ }^{8}$ Nation, LXXII (May 9, I901), 368-69.

${ }^{\circ}$ William Barclay Parsons, "The American Invasion of China," McClure's Magazine, XIV (April I900), 499-510; Charles Denby, "Our Relations With the Far East," Munsey's, XX (Jan. 1899), 515-20. 
it was apparent that the dawn of a new century would spell the awakening of China from the somnolence of centuries and "what we regard as progress will be greatly accelerated." W.W. Rockhill, drafter of the I 899 Open Door note and student of Chinese affairs felt there were no alternatives for the empire save "develop or decay." Reform, Rockhill wrote in Collier's, must "come from without . . . under direct pressure from abroad."10

In the articles Griffis clipped, almost all the authors shared part of the dream of America in China's future. Some like Mark Twain dissented. "To the Person Sitting in Darkness" Twain announced his complete support of the anti-foreign drive of the Chinese Boxers in I900. "It is all China, now, and my sympathies are with the Chinese," declared a man never reconciled to the Gilded Age and what came after. Striking out at his missionary critics, Twain stated what was almost the sole negation of the commercial, investment and reform ambitions of the Open Door policy: "We have no more business in China than in any other country that is not ours."11 In an earlier characterization of the Chinese, Twain had found them a harmless race when let alone-quiet, peaceable, free from drunkenness and most industrious. Seeing the $400,000,000$ Chinese as stereotypes, Twain was here far more in step with his peers than in his views of the Open Door. ${ }^{12}$ Ironically, the persistent American image of the Chinese, which Twain shared, usually pictured a people who could but benefit from the very involvement Twain so openly protested.

John Chinaman, to use the popular term of the day, was helpless yet industrious, frugal yet honest, indifferent yet successful in business. There were two sides to the image of the Chinese. They could be wise, friendly, reliable and scholarly, or ignorant, cruel, lazy and backward. The stereotypes were widespread among muckrakers like Steffens who seemed to feel the Chinese could predict the weather but

10 The World's Work, III (Dec. I 90I), I 475-76; W.W. Rockhill, "The Outlook in China," Collier's, XXVIII (Jan. 4, 1902), 9.

${ }^{11}$ Mark Twain, "To The Person Sitting in Darkness," North American Review, CLXXII (Feb. I90I), I6I-76; "To My Missionary Critics," North American Review, CLXXII (April i 901 ), 520-34.

${ }_{12}$ Mark Twain, Roughing It (Hartford, 1872), ch. 54. The Griffis Papers abound in stereotyped views of the Chinese; see, for example, McClure's Magazine, XVI (Dec. I 900 ), I $34-40$. 
could only be employed to fish and launder. The determining factor was that a Chinese in China had all the good virtues while a Chinaman in the United States took on all the bad habits. American attitudes toward China as reflected in the press were dichotomized between the benefits of the Open Door abroad and the fears of the yellow peril at home. ${ }^{13}$

At the end of the first decade of the twentieth century, the negative side of the image threatened to dissolve as the press extended its excited coverage to include detailed reports of political upheaval in China. The IgI I revolution and the rise of a republic under a "progressive" Yuan Shih-kai to replace a crumbling Manchu empire indicated to Americans like Griffis that "China means to become a nation in the western sense of the word." The goals of American policy would now be reached that much sooner with a government anxious to continue work to improve China's canals, modernize its industry and agriculture and reorganize an antiquated administrative system. The gospel of efficiency, so eulogized by the muckrakers, was seen by sociologist E.A. Ross as the chief beneficiary of the revolution. An intelligent government, one that was just and efficient would make enormous strides "in the introduction of western technique and organization," Ross reasoned for LaFollette's Magazine. Seeing the revolution not in political terms but in the commercial, financial and reform goals of the Open Door, Ross was sure that it would mean machinery, railways, telegraphs, post offices, sanitation, education, conservation and even modern dress. ${ }^{14}$

While Ross went on to draw the "perilous" racial conclusion that the yellow man would now join with the white in "controlling the globe" and eventually molding the "politics of the planet," others were convinced that all would now be better for "as the French Revolution was inspired by America's success, so China's revolution

${ }^{13}$ Lincoln Steffens to Laura Suggett, Aug. I 9,1925 and to his son Pete, Aug. 14 , Sept. I 9, I 925, in Ella Winter and Granville Hicks eds. The Letters of Lincoln Steffens (New York, I938), II, 705, 845-46, 857. See the brilliant work of Harold Isaacs, Scratches on Our Minds, American Images of China and India (New York, 1958).

${ }^{14}$ The Outlook, XCVII (Feb. 4, I9II), 249-50; CII (Nov. 30, 1912), 700-01. E. A. Ross, "The Overturn in China," La Follette's Magazine, III (Dec. 2, I91 I), 7; and Ross, "Race Mind of the Chinese," The Independent, LXXI (Sept. 7, 19II), 526, 528 . 
was brought about and won by America's education." The image of China as a reincarnation, as a tabula rasa for American business and especially American reform was never clearer than in articles written just after the revolution. "China is as large as the United States," Frederick McCormick suddenly remembered in December i9 I I. It also, he noted, "lies in the same latitude, has similar physical characteristics, and the same kind of climate." Sensing the same geographical analogy, agriculturalist F.H. King asked Americans to picture China's Grand Canal as similar to the stretch of land from either the Rio Grande to the Ohio or the Mississippi to Chesapeake Bay. In a most revealing "expansion of the frontier of the United States westward to the interior of China," as Theodore Roosevelt had earlier proclaimed, E.A. Ross found "The Far West of the Far East," the remote province of Szechuan, to be the most energetic the American part of China. ${ }^{15}$

Summarizing such American interest in China after the I9I I revolution, The Outlook thought "the new government has the sympathy of Progressives everywhere." As the magazine clippings in the William Elliot Griffis Collection reveal, this was surely a fitting description of the attitude of those who had been reporting developments at home and in China for the previous decade. The Griffis file of articles provides an excellent starting place for historical research into the shaping of American foreign policy in the early twentieth century. The sensational stories and circulations of the magazines subsided shortly after I9I2; however, the problems of American opportunity in China, widely publicized in the muckraking era, lived on, until John Chinaman's "bad" side showed itself again some four decades later.

${ }^{15}$ Frederick McCormick, "Present Conditions in China," National Geographic Magazine, XXII (Dec. IgाI), тгго; F.H. King, "The Wonderful Canals of China," National Geographic Magazine, XXIII (Oct. 1912), 931-58.

${ }^{16}$ The Outlook, CII (Oct. 5, 1912), 237. 